\title{
Children's rights education: An imperative for health professionals
}

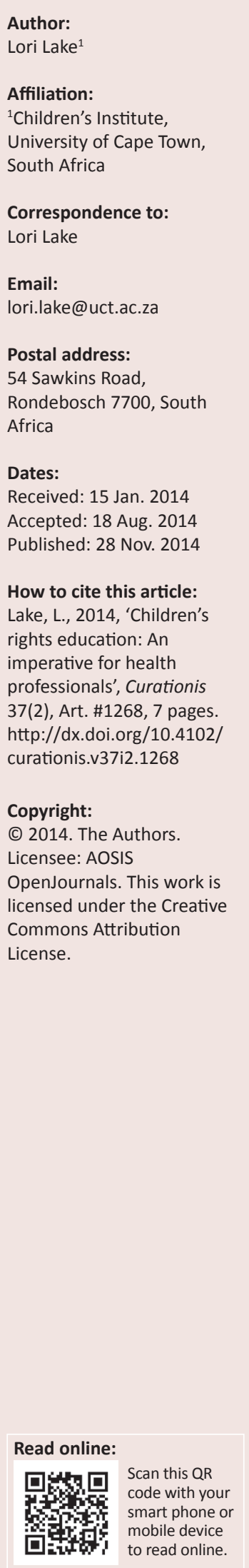

The South African government has put in place a range of laws, policies and programmes that are designed to give effect to children's rights and support children's survival, health and optimal development. These rights do not just exist on paper. They have the potential to transform professional practice and improve the quality of care across a range of health care services. A child-rights' approach requires nurses to act in the best interest of children, respect their evolving capacities, think more holistically about a child's well-being and work with others to address the broader social determinants of health - such as access to food, water and sanitation. This article draws on lessons learned from a short course in children's rights and child law for health professionals offered by the Children's Institute, University of Cape Town from 2011-2014. It encourages nurses to reflect critically on their current practice and to take action to improve a child's well-being. It also advocates for the inclusion of children's rights to be at the heart of education and training, professional codes of conduct and standards of care.

\section{Introduction}

Children's rights are a powerful tool for enhancing the quality of care for children in South Africa's health care system, yet child rights and child law are rarely included in nursing and medical curricula. Many health professionals therefore remain unaware of children's rights and fail to fulfil their legal obligations as outlined in the Bill of Rights (South Africa 1996) and Children's Act (South Africa 2005).

This article draws on lessons learned from a short course in child rights and child law for health professionals developed in 2011 by the Children's Institute, University of Cape Town, in collaboration with the Institute for International Child Rights and Development at the University of Victoria, Canada (Lake \& Proudlock 2011). ${ }^{1}$ It provides a brief introduction to children's rights in international and South African law and then considers the implications for professional practice, the health care system and the wider community.

\section{Children's rights to health in international and South African law}

Children's rights to health in international law are defined by the International Convention on Economic, Social and Cultural Rights (2000), the United Nations Convention on the Rights of the Child (2013), and the African Charter on the Rights and Welfare of the Child (OAU 1990). ${ }^{2}$

The International Convention on the Social, Economic and Cultural Rights recognises 'the right of everyone to the highest standard of physical and mental health' - including children (Office of the High Commissioner of Human Rights 1966:Article 12). This right to health has been interpreted broadly by the United Nations Committee on Economic, Social and Cultural Rights (2000) as:

\footnotetext{
... an inclusive right extending not only to timely and appropriate health care; but also to the underlying determinants of health, such as access to safe and potable water and adequate sanitation, an adequate supply of safe food, nutrition and housing, healthy occupational and environmental conditions; and access to health related education and information, including on sexual and reproductive health. A further important aspect is the participation of the population in all health related decision making at the community, national and international levels. (p. 11)
}

Article 24 of the United Nations Convention on the Rights of the Child (Office of the High Commissioner of Human Rights 1989) provides a similar definition of children's right to health. In its recently released General Comment 15, the United Nations Committee on the Rights of the Child

\footnotetext{
The course is accredited by the Health Professions Council of South Africa, and enables nurses, doctors, social workers and allied health professionals working across a range of clinical settings to deepen their understanding of children's rights and child law, to critically professionals working across a range of clinical settings to deepen their understanding of children's rights
reflect on current practice, and consider how children's rights can be used to enhance the quality of care.

2.The African Charter provides similar guidance to the United Nations Convention on the Rights of the Child (UNCRC) and will therefore
} not be explicitly dealt with here. 
stressed that children's right to health is an inclusive right and cannot be considered in isolation from children's other rights (2013:ss. 2, 7). For example, children's right to health depends on the realisation of their rights to water, food and shelter, as well as their rights to information and education. In other words, children's rights are interdependent and indivisible.

This broad definition of the right to health is given effect through a range of socio-economic and political rights in the South African Constitution, as illustrated in Figure 1. Children ${ }^{3}$ share the same basic rights as adults - except the right to vote and hold political office. For example, everyone has the right to equality, dignity, freedom from violence and an environment that is not harmful to their health.

Children are also entitled to additional protection, and section 28 of the South African Bill of Rights outlines children' rights to family or alternative care, basic health care services, protection from abuse and neglect, and the right to have their best interests considered of paramount importance in every matter that affects the child (South Africa 1996). Government has put in place a range of laws, policies and programmes which help translate children's rights into a basket of goods and services for children and families.

\section{What are the implications for health professionals?}

Children's rights can be seen as both a 'legal obligation and a moral injunction' (Pendlebury \& Lake 2009). At times there is a clear and direct relationship between children's rights, laws, policies and programmes. For example, children in South Africa have the right to be protected from abuse and neglect. This is given effect by Section 10 of the Children's Act (South Africa 2005) which outlines health professionals' legal obligation to report physical abuse causing injury, sexual abuse and deliberate neglect; and failure to do so can result in prosecution.

But it is important to guard against 'constitutional romanticism' (Spreen \& Vally 2006). Just because children's rights are written into the Constitution, does not mean that they are a reality in children's lives. Health professionals therefore have a moral obligation to promote children's health and best interests within the health care system, and to speak out when children's rights are violated. This is particularly important in a country where children are rarely given the opportunity to speak out for themselves. Nurses and doctors also have intimate knowledge of how poverty and violence impact on the health and development of children in their communities. And, through their participation in district health councils and committees, nurses can play a key leadership role in identifying local health risks and contributing to policies and programmes that address these broader social determinants of health.

3.In South African law, children are defined as people under the age of 18 (0-17-years-old).
Children's rights in South Africa also are justiciable, and the courts have proven an effective mechanism for holding the State accountable and ironing out inconsistencies between rights, laws and policies. For example: the Treatment Action Campaign (TAC) took the Minister of Health to court and used women and children's right to basic health care services to force Government to roll-out prevention of mother-tochild transmission services (Minister of Health v Treatment Action Campaign 2002).

The TAC court case provides one example of how children's rights can serve as a powerful tool for transformation at a national level. However most changes start much closer to home, where nurses and nurse educators can use children's rights to:

- enhance professional practice

- set standards for child- and family-friendly care

- address the broader social determinants of health

- and develop a workforce tasked with promoting children's optimal development.

\section{Enhancing professional practice: Participation, consent and respect for evolving capacities}

Change starts with the self, and there is much that nurses can do to give effect to children's rights in their interactions with children and their caregivers, for example, greeting the child by name, helping caregivers access the Child Support Grant, and respecting children's privacy and confidentiality.

A human rights culture is founded on dignity and respect for all - regardless of race, class, gender, age or ability. When children are very young they are dependent on the guidance and protection of their parents and caregivers. Yet, as children develop and grow, they become increasingly able to take responsibility for their own health care. Therefore, it is vital that health professionals wherever possible involve children and families as active partners in their own health care.

In 2010, the Children's Act (South Africa 2005, was gazetted in 2005 and only came into effect in 2010) formally introduced children's right to participate in health care decision-making in line with their evolving capacities. This Act also outlines new consent provisions for medical treatment, surgery, HIV testing and disclosure. For example, children aged 12 and older can consent to (and refuse) medical treatment provided that they are mature enough to understand the risks, benefits and social consequences. The Act recognises that the child's capacity to understand may vary with age, education, life circumstances and the nature of the illness and treatment involved, so the onus lies on the health professional to establish on a case-by-case basis if the child meets the maturity requirements.

These consent provisions require a fundamental shift in the way health professionals engage with children: nurses and doctors need to provide information in child-friendly formats and give children an opportunity to ask questions and express their views. Only then is it possible to assess 


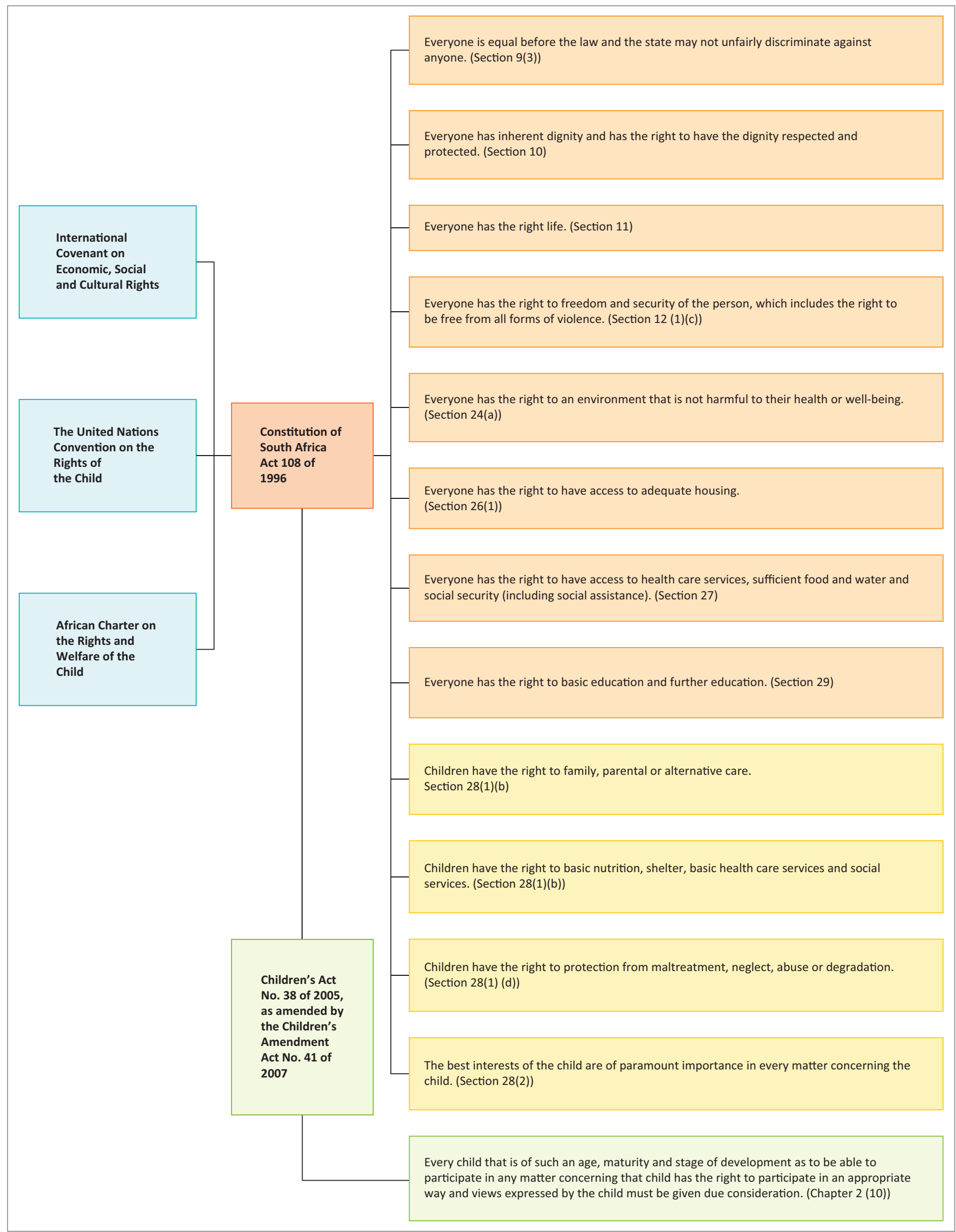

Source: Proudlock, P. \& Mahery, P., 2010, 'Children's rights to health', in M. Kibel, L. Lake, S. Pendlebury \& C. Smith (eds.), South African Child Gauge 2009/2010, pp. 22-28, Children's Institute, University of Cape Town, Cape Town

FIGURE 1: How the Constitution and Children's Act give effect to children's international rights to health. 
whether the child is mature enough to understand the risks and benefits (Jamieson \& Lake 2013).

Children's right to participate and express their views also applies to younger children, as it is only by understanding children's symptoms and fears that health professionals are able to act in their best interests. Involving children as partners in health care has clear benefits for children and health professionals. It alleviates children's fear and distress, and helps children cope and comply better with treatment (Kruger \& Coetzee 2011). Children often struggle to make themselves heard and may express their discomfort and frustration through resisting, turning away or becoming silent. Whilst these patients may be considered 'difficult', children who are quiet, sick or shy are most likely to become 'invisible', and have their basic needs overlooked (Lambert, Glacken \& McCarron 2008). Listening and responding to children has been found to improve treatment success, reduce hospital errors and improve patient satisfaction with health care (Costello, Patak \& Pritchard 2010). Even young babies are capable of expressing their views, so it is vital that nurses are able to read signs of distress and find ways to minimise pain and discomfort, for example, by using the Face, Legs, Activity, Cry, Consolability (FLACC) scales to assess children's pain, and by encouraging mothers to hold or breastfeed babies during painful procedures.

Other rights that need to be considered in individual practice include children's rights to dignity, privacy and confidentiality, particularly in the context of adolescence and reproductive health services.

\section{Developing standards for child and family-friendly health care}

Whilst there is much that can be done to implement children's rights in individual practice, it is also important to evaluate the extent to which the health care system and individual health care facilities give effect to children's rights. Twenty years into democracy, stark inequities persist between private and public sectors, and between urban and rural areas in South Africa. Private health insurance accounts for $44 \%$ of all health care spending in South Africa; but it serves only $15 \%$ of the population (McIntyre 2010). Nearly half of South Africa's children live in rural areas (Hall 2013c), yet only $12 \%$ of doctors and $19 \%$ of nurses work there (South Africa, Department of Health 2011a). So it is important to advocate for a more equitable and child-centred distribution of resources and to actively address barriers to health care.

National Health Insurance (and the re-engineering of primary health care) aims to address these disparities and promote universal coverage (Matsotso \& Fryatt 2013), whilst the National Core Standards for Health Establishments (NCS) aim to improve the quality of care at both public and private health establishments with a strong emphasis on patient rights (South Africa, Department of Health 2011b). However, an initial baseline audit conducted in 2011 (Health Systems Trust 2012:14) highlighted poor compliance with six ministerial priority areas: with facilities scoring particularly low on positive and caring attitudes $(30 \%)$, patient safety and security (34\%), and slightly better on cleanliness (50\%), infection prevention and control (50\%), availability of medicine and supplies (54\%), and waiting times (68\%).

The NCS offer an opportunity to improve the quality of care for children, yet children's needs are rarely considered outside of paediatric and neonatal wards (Malek 2011). Therefore, it would be useful to complement the NCS with more child-friendly standards of care. The Child Friendly Healthcare Initiative (Nicholson \& Clarke 2001) has used a rights-based approach to develop a set of standards for child-friendly care, as outlined in Box 1 . These standards are supported by a training manual and set of practical tools that enable health facilities to assess their own practice, identify areas for improvement and measure progress.

It is equally important to consider what children's rights look like for children of different ages and in different contexts. For example, the Baby-Friendly Hospital Initiative (Naylor 2001) considers the best interests of the mother and neonate; whilst Youth-Friendly Services (Kirby 2007) aim to make sexual and reproductive health services accessible and acceptable to young people. These initiatives highlight the critical role of nurses and other health professionals in defining how best to give effect to children's rights within a particular hospital or clinic environment - ideally in collaboration with patients and their caregivers.

The Phila Impilo project, for example, worked with children in chronic care at Clarewood Hospital, in Durban and used children's experiences of the hospital to drive a quality improvement process (De Wet, Kruger \& Black 2009). The children made a number of recommendations to improve safety, hygiene, food, medical care, and relationships with their families. These ideas were then taken forward by staff and the hospital extended visiting hours and limited staff

\section{BOX 1: Twelve standards for child-friendly care.}

1. Keep children out of hospital unless admission is absolutely necessary.

2. Support and give the best possible care.

3. Provide care safely in a secure and clean child-friendly environment

4. Give child- and family-centred care in partnership with parents, in areas dedicated to children and young people, by trained and experienced paediatric staff who can enable parents/carers to support children during painful procedures.

5. Keep parents and children fully informed and involved in all decisions affecting their care.

6. Approach children without discrimination as individuals. Each child has his/ her own age-appropriate and developmental needs and can be involved at his/her level of competence. Each has a right to privacy and dignity.

7. Recognise and relieve pain and discomfort.

8. Give appropriate resuscitation, emergency and continuing care for very sick children.

9. Enable play and learning.

10. Recognise, protect and support vulnerable and abused children.

11. Monitor and promote health whenever a pregnant woman or child attends a health care facility.

12. Support the best possible nutrition, including breast-feeding.

Source: Adapted from: Nicholson, S. \& Clarke, A., 2007, Child Friendly Healthcare: A manual for health workers, Childhealth Advocacy International, Nottingham, viewed 14 October 2014, from http://www.cfhiuk.org/publications/cfhi_manual.htm 
rotation to enhance continuity of care and ensure that only nurses interested in working with children were allocated to the paediatric wards.

\section{Addressing the broader social determinants of health: Intersectoral collaboration}

Whilst there are number of ways in which nurses can use children's rights to enhance the quality of care in their facilities, it is equally important to consider children's rights outside the health care service. Children are disproportionately affected by poverty in South Africa, and nearly $60 \%$ of children live in households with a monthly per capita income of less than R575 (Hall 2013a).

Poverty, hunger, violence and poor access to services have a cumulative impact on children's health and development (Walker et al. 2007). For example $26 \%$ of children aged 0-3-years old are stunted (Shisana et al. 2013). These children are likely to get sick more often and to struggle at school, which in turn compromises their future prospects for employment and drives an intergenerational cycle of poverty and ill health.

There is a growing recognition that the first 1000 days of life (from conception to when children turn two years old) lay the foundation for future health and cognitive development (Berry, Dawes \& Biersteker 2013), and within the policy environment there are calls for the health service to play a more proactive role in supporting not just child survival but children's optimal development (Slemming \& Saloojee 2013).

With rights come responsibilities, and a child-rights approach provides a powerful framework for addressing these broader social determinants of health. Not only does it emphasise a holistic approach to health that extends beyond the absence of illness and infirmity to support a state of complete physical, mental and social well-being (World Health Organisation 1946). It also identifies health care professionals as one of a range of duty bearers who are responsible for giving effect to children's rights - starting with the family and extending outwards to include service providers and policy makers. This echoes Bronfenbrenner's ecological approach to child development (Ball, Bindler \& Cowen 2010) and highlights the importance of considering the child in context. There is much that nurses can do to strengthen these circles of support by actively involving family and caregivers as partners in health (for example, through the home- and community-based Integrated Management of Childhood Illness [IMCI]) and by developing effective referral systems.

This kind of intersectoral collaboration is a critical component of primary health care re-engineering where nurses are expected to play a leadership role in building relationships with other service providers and following up on referrals so that children do not fall through the cracks. This role includes supporting caregivers of poor children to access the Child Support Grant, which is associated with positive health, nutrition and education outcomes (Case, Hosegood \& Lund 2005).

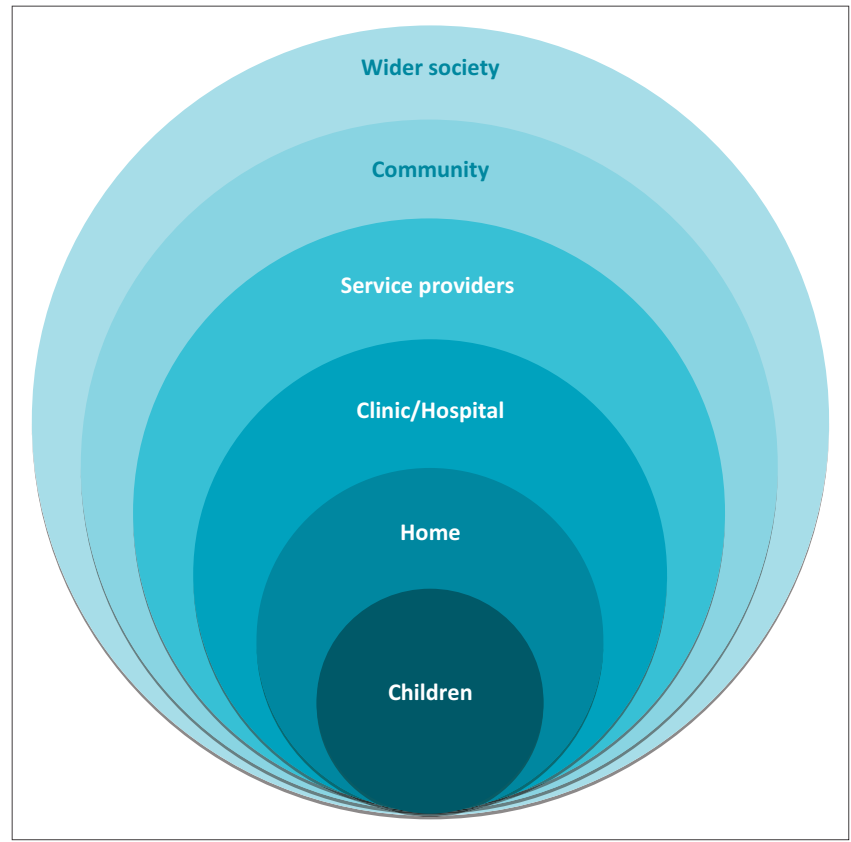

Source: Adapted from: Lake, L., Proudlock, P., Nhenga-Chakarisa, T. Mahery, P. \& Lansdown, G., 2011, 'Module 1: Child health and children's rights', in L. Lake \& P. Proudlock (eds.), Child
rights and child law for health professionals: A short course, pp. 1-23, Children's Institute, University of Cape Town

FIGURE 2: Strengthening circles of support.

\section{Building a workforce to enhance child care and development}

Ultimately, South Africa needs to build a children's healthcare workforce equipped with the knowledge and skills to give effect to children's rights in practice. The United Nations Committee on the Rights of the Child has outlined states' obligations to develop child rights training and capacity building for all those working with and for children-including nurses, doctors and allied health care professionals. This training should be: 'systematic, ongoing and incorporated into professional training curricula, codes of conduct and educational curricula at all levels' (2003:Article 53).

Recognising and actively considering children's rights in nursing education is not simply a legal obligation. It is a practical necessity. Children account for $40 \%$ of the population, with over 18 million South Africans under the age of 18 (Hall 2013b). This means children comprise a significant proportion of the patient load at all levels of the health care system, and that all nurses - not just those working on paediatric or neonatal wards - need to be equipped with the knowledge and skills to give effect to children's rights in their clinical practice.

The United Kingdom has established national occupational standards that cut across health and social services, and that are organised into care pathways that highlight the importance of tightening up referrals and transitions between different services to promote continuity of care (Skills for Care \& Skills for Health 2013). Each care pathway is broken down into occupational standards. For example: communicate with children, young people and those involved in their care; comply with legal requirements for patient and/or client confidentiality; recognise and respond to possible abuse 
of children and young people; and provide information about children and families' services. Each standard then spells out the required knowledge, skills and performance criteria - which can be used to structure education and training as well professional codes of conduct.

This may prove a useful framework for developing local curricula and spelling out the core competencies that nurses, doctors and other health and social service professionals require in order to give effect to children's rights and legal entitlements.

Efforts to integrate a child-rights approach into pre- and in-service education are particularly pressing given the leadership role nurses are expected to play within the re-engineering of primary health care in the district specialist, school health and ward outreach teams (Matsotso \& Fryatt 2013). Within this context, a child-rights approach provides a potentially powerful framework that nurses can draw on to promote child health, improve quality and strengthen intersectoral collaboration.

\section{Acknowledgements}

This article draws on a presentation made at the Building Children's Nursing for Africa conference, UCT, 17-19 April 2013 as well as the Children's Institute short course on Child rights and child law for health professionals which was developed in collaboration with Paula Proudlock, Lucy Jamieson, Prinslean Mahery, Tendai Nhenga-Chakarisa and Gerison Lansdown who have provided invaluable guidance in helping me navigate the complex relationships between child rights and child law. I would also like to thank the many nurses, doctors, social workers and allied health professionals who have attended the course and found innovative ways of giving effect to children's rights in health care practice. I remain humbled and inspired by your work as champions for children.

\section{Competing interests}

The author declares that he or she has no financial or personal relationship(s) that may have inappropriately influenced him or her in writing this article.

\section{References}

Ball, J.W., Bindler, R.C. \& Cowen, K.J., 2010, Child health nursing: Partnering with children and families, 2nd edn., Pearson, New Jersey.

Berry, L., Dawes, A. \& Biersteker, L., 2013, 'Getting the basics right: An essentia package of services and support for ECD', in L. Berry, L. Biersteker, A. Dawes, L. Lake \& C. Smith (eds.), South African Child Gauge 2013, pp. 26-33, Children's Institute, University of Cape Town, Cape Town.

Case, A., Hosegood, V. \& Lund, F., 2005, 'The reach and impact of Child Support Grants: Evidence from KwaZulu-Natal', Development Southern Africa 22(4), October 2005, 467-482. http://dx.doi.org/10.1080/03768350500322925

Costello, J.M., Patak, L. \& Pritchard, J., 2010, 'Communication vulnerable patients in the pediatric ICU: Enhancing care through augmentative and alternative communication', Journal of Pediatric Rehabilitative Medicine, 3(4), 289-301.

De Wet, T., Kruger, J. \& Black, V., 2009, Phila Impilo: Live Life! Ways to Healing, Children as Partners in Health, Young Insights in Planning, Overpoort.

Hall, K., 2013a, 'Demography - Number and proportion of children living in South Africa', Children's Institute, University of Cape Town, viewed 10 January 2014, from http://www.childrencount.ci.org.za
Hall, K., 2013b, 'Income and social grants - Number and proportion of children living in income poverty', Children's Institute, University of Cape Town, viewed 10 January 2014, from http:// www.childrencount.ci.org.za

Hall, K., 2013c, 'Housing and services - Urban-rural distribution', Children's Institute, University of Cape Town, viewed 10 January 2014, from http://www. childrencount.ci.org.za

Health Systems Trust, 2012, National Health Care Facilities Baseline Audit: Summary Report, Health Systems Trust, Durban.

Jamieson, L. \& Lake L., 2013, Children's Act guide for health professionals, 5th edn., Children's Institute, University of Cape Town, Cape Town.

Kibel, K., Lake, L., Pendlebury, S. \& Smith, C., 2010 , South African Child Gauge 20092010, Children's Institute, University of Cape Town, Cape Town.

Kirby, S., 2007, Youth-friendly services toolkit, LoveLife, Johannesburg.

Kruger, J. \& Coetzee, M., 2011, 'Children's relationships with professionals', in L. Jamieson, R. Bray, A. Viviers, L. Lake \& C. Smith (eds.), South African Child Gauge 2010/2011, pp. 36-42, Children's Institute, University of Cape Town, Cape Town.

Lake, L. \& Proudlock, P., (eds.), 2011, Child rights and child law for health professionals: A short course, Children's Institute, University of Cape Town and International Institute for Child Rights and Development, University of Victoria.

Lake, L., Proudlock, P., Nhenga-Chakarisa, T. Mahery, P. \& Lansdown, G., 2011 , 'Module 1: Child health and children's rights', in L. Lake \& P. Proudlock (eds.), Child rights and child law for health professionals: A short course, pp. 1-23, Children's Institute, University of Cape Town.

Lambert, V., Glacken, M. \& McCarron, M., 2008, “Visible-ness': The nature of communication for children admitted to a specialist children's hospital in the communication for children admitted to a specialist children's hospital in the
Republic of Ireland', Journal of Clinical Nursing 17(23), 3092-3102. http://dx.doi. Republic of Ireland', Journal of Clinical N
org/10.1111/j.1365-2702.2008.02462.x

Malek, E., 2011, 'Tygerberg Academic Hospital NCS Baseline Audit 29 August-5 September 2011, Comments \& Proposals', Department of Paediatrics \& Child Health, Tygerberg 2011, Comments \& Proposals, Department of Paediatrics \& Child Health,
Hospital, Cape Town. (Submission to National Core Standards audit team).

Matsotso, M.P. \& Fryatt, R., 2013, 'National Health Insurance: The first 18 months', in A. Padarath \& R. English (eds.), South African Health Review 2012/13, pp. 21-36, Health Systems Trust, Durban.

McIntyre, D., 2010, ' Private sector involvement in funding and providing health services in South Africa: Implications for equity and access to health care', Health Economics Unit, University of Cape Town \& Institute for Social and Economic Research, Rhodes University, EQUINET, Harare. (Equinet discussion paper, 84).

Naylor, A.J., 2001, 'Baby-friendly hospital initiative: Protecting, promoting, and supporting breastfeeding in the twenty-first century', Pediatric Clinics of North America 48(2), 475-483. http://dx.doi.org/10.1016/S0031-3955(08)70039-7

Nicholson, S. \& Clarke A., 2001, 'How child-friendly are you?', Paediatric Nursing 13(5), 12-15.

Nicholson, S. \& Clarke, A., 2007, Child Friendly Healthcare: A manual for health workers, Childhealth Advocacy International, Nottingham, viewed 14 October 2014, from http://www.cfhiuk.org/publications/cfhi_manual.htm

Office of the High Commissioner of Human Rights, 1966, 'International Covenant on Economic, Social and Cultural Rights', UN General Assembly resolution 2200A, United Nations, Geneva.

Office of the High Commissioner of Human Rights, 1989, 'Convention on the Rights of the Child', UN General Assembly resolution 44/25, United Nations, Geneva.

Organisation of the African Union (OAU), 1990, African Charter on the Rights and Welfare of the Child, OAU resolution 21.8/49, Organisation of the African Union, Addis Ababa.

Pendlebury, S. \& Lake, L., 2009, 'Children's right to basic education', in S. Pendlebury, L. Lake \& C. Smith (eds.), South African Child Gauge 2008/2009, pp. 19-23, Children's Institute, University of Cape Town, Cape Town.

Proudlock, P. \& Mahery, P., 2010, 'Children's rights to health', in M. Kibel, L. Lake, S. Pendlebury \& C. Smith (eds.), South African Child Gauge 2009/2010, pp. 22-28, Children's Institute, University of Cape Town, Cape Town.

Shisana, O., Labadarios, D., Rehle, T., Simbayi, L., Zuma, K., Dhansay, A. et al. \& the SANHANES-1 Team, 2013, South African National Health and Nutrition Examination Survey (SANHANES-1), HSRC Press, Cape Town.

Skills for Care \& Skills for Health, 2013, Code of Conduct for Healthcare Support Workers and Adult Social Care Workers in England, viewed 22 September 2014, from http://www.skillsforcare.org.uk \& http://www.skillsforhealth.org.uk

Slemming, W. \& Saloojee, H., 2013, 'Beyond survival: The role of health care in promoting ECD', in L. Berry, L. Biersteker, A. Dawes, L. Lake \& C. Smith (eds.), South African Child Gauge, pp. 50-55, Children's Institute, University of Cape Town, Cape Town.

South Africa, 1996, Constitution of the Republic of South Africa, (Chapter 2), Bill of Rights, Government Gazette, Government Printers, Pretoria.

South Africa, 2002, Constitutional Court of South Africa, Minister of Health and others v Treatment Action Campaign and others (No. 2) 2002 (5) SA 721, viewed 14 October 2014, from http://www.saflii.org/za/cases/ZACC/2002/15.pdf

South Africa, 2005, Children's Act (No. 38 of 2005), Government Gazette, Government Printers, Pretoria.

South Africa, Department of Health, 2011a, Human Resources for Health South Africa: HRH Strategy for the Health Sector: 2012/13 - 2016/17, Department of Health, Pretoria.

South Africa, Department of Health, 2011b, National Core Standards for Health Establishments in South Africa (abridged version), Department of Health, Tshwane.

Spreen, C.A. \& Vally, S., 2006, 'Education rights, education policies and inequality in South Africa', International Journal of Educational Development 26, 352-362. $\mathrm{http}: / / \mathrm{dx}$.doi.org/10.1016/j.ijedudev.2005.09.004 
United Nations Committee on Economic, Social and Cultural Rights, 2000, 'The right to the highest attainable standard of health', General Comment No. 14 E/C.12/2000/4, United Nations, Geneva.

United Nations Committee on the Rights of the Child, 2003, 'General Measures of Implementation of the Convention on the Rights of the Child', General Comment 5 , CRC/GC/2003/5, United Nations, Geneva. (United Nations Committee on the Rights of the Child [UNCRC]).

United Nations, Committee on the Rights of the Child, 2013, 'The right of the child to the enjoyment of the highest attainable standard of health (art. 24)', Genera Comment No. 15, CRC/C/GC/15, United Nations, Geneva.
United Nations, Office of the High Commissioner of Human Rights 1989, Convention on the Rights of the Child, UN General Assembly resolution 44/25, United Nations, Geneva.

Walker, S.P., Wachs, T.D., Meeks Gardner, J., Lozoff, M.D., Wasserman \& the International Child Development Steering Group , 2007, 'Child development: Risk factors for adverse outcomes in developing countries.' The Lancet 369, 145-157. http://dx.doi.org/10.1016/s0140-6736(07)60076-2

World Health Organization (WHO) Constitution, 1946, Preamble to the Constitution of the World Health Organisation (WHO) as adopted by the International Health Conference, New York, 22 July 1946, viewed 14 October 2014, from http://www. who.int/governance/eb/who_constitution_en.pdf 